Original Research

\title{
The Differences of Inpatients' Satisfaction Level based on Socio-Demographic Characteristics
}

\section{Ni Komang Ayu Adnya Dewi, Ni Putu Emy Darma Yanti, and Kadek Saputra}

Faculty of Nursing, Universitas Udayana, Bali, Indonesia

\section{ABSTRACT}

Introduction: Assessing the quality of nursing care has become a global health issue. especially for caregivers and recipients of care in the inpatient department. Patient satisfaction is one of the indicators to measure quality of nursing care. This study aimed to identify the differences of patient satisfaction level in inpatient ward based on socio-demographic characteristics at Siloam Hospitals Bali.

Methods: This study was cross-sectional design with descriptive comparative and correlation methods. Patient satisfaction data were collected using the Patient Satisfaction with Nursing Care Quality Questionnaire (PSNCQQ) that was provided after the patient was discharged. Purposive sampling technique was used to determine 107 samples. The analytical tests used in this study were the Spearman correlation test, Mann-Whitney test and Kruskal-Wallis test.

Results: The results of this study showed that there was a significant weak and negative correlation between the level of satisfaction and age of the patient $(\mathrm{p}=$ $0.017 ; r=-0.231 ; \alpha<0.05)$. There were significant differences of patient satisfaction based on marital status $(\mathrm{p}=0.036 ; \alpha<0.05)$ and nationality status ( $p=0.001 ; \alpha<0.05)$, but there were no differences in patient satisfaction based on $\operatorname{sex}(\mathrm{p}=0.276 ; \alpha<0.05)$ and education level $(\mathrm{p}=0.434 ; \alpha<0.05)$.

Conclusion: This study concluded that social demographic characteristics of patients can influence the satisfaction, but only on age, marital and nationality status. This showed that inpatients provide good satisfaction evaluations of nursing care. The optimal nursing care needs to be maintained and improved, either routine evaluation or sustainable program development.
\end{abstract}

\section{ARTICLE HISTORY}

Received: July 09, 2020

Accepted: August 11, 2020

\section{KEYWORDS}

nursing service quality; patient satisfaction.

\section{CONTACT}

Ni Komang Ayu Adnya Dewi $\triangle$ ayu.adnyadewi@gmail.com $\equiv$ Faculty of Nursing, Universitas Udayana, Bali, Indonesia

Cite this as: Dewi, N. K. A.A., Yanti, N. P. E. D., \& Saputra, K. (2020). The Differences of Inpatients' Satisfaction Level based on Socio-Demographic Characteristics. Jurnal Ners, 15(2). 148-156. doi:http://dx.doi.org/10.20473/jn.v15i2.20610

\section{INTRODUCTION}

Health has now become one of the main goals of the Sustainable Development Goals (SDGs) for 2030, which states that everyone has the right to achieve universal health coverage, including affordable medicines, accessibility, safe and effective quality of services and access to quality essential health services (World Health Organization, 2015). High health needs demand facilities and health service providers to perform better quality services and comply with established standards.

The health services quality was previously measured only by using professional standards and ignored the patient satisfaction value. Nevertheless, some findings revealed that patient satisfaction as an indicator to measure the health services quality. Patient satisfaction is defined by the happiness level by the patient during treatment or the patient's perception about the care received while treated in hospital (Worku \& Loha, 2017). Patient satisfaction surveys can directly evaluate whether the extent of the care provided is able to meet the patient's health needs (Price et al., 2014).

The Ministry of Health Republic of Indonesia Act Number 129 Year 2008 established a minimum service standard for patient satisfaction of $\geq 90 \%$. If health services are found with patient satisfaction levels lower than $90 \%$, it could be assumed that the health services provided did not meet with the minimum standards or no quality. The patient satisfaction percentage in Indonesia obtained from 
one central hospital was $77.1 \%$ (Novitasari et al., 2014), at regional hospitals was $83.3 \%$ (Mustika \& Sari, 2019), and at private hospitals was 54.52\% (Oini et al., 2017). These show that the picture of patient satisfaction level in Indonesia is still under the minimum standard established.

Variations in the patient satisfaction level with the service quality could be affected by several factors. Chen et al. (2019) revealed that there are nonmodifiable factors that affect the patient satisfaction levels with variations such as age, sex, race and socioeconomic status. The patient satisfaction level also could be affected by several factors originating from the health services themselves, such as reliability, responsiveness, assurance, empathy and service quality (Mumu et al., 2015Sulistyo et al. (2019) stated that the funding sources, treatment duration and accreditation status could also affect patient satisfaction.

Patients who are satisfied with the treatment given will tend to adhere to the healthcare provider's treatment plan (Mohan \& Kumar, 2011). Patient satisfaction also provides benefits to health services such as making patients loyal and increasing the visits percentages. Loyal patients will visit the same health service if they need back-to-back treatment (Nursalam, 2014), whereas for patients who are dissatisfied, services will lead to lower utilization of health services. Other forms of negative attitudes due to dissatisfaction could show as verbally influencing others to not to seek healthcare (Debono \& Travaglia cited in Mukhtar et al., 2013).

Efforts made to improve the patient satisfaction with health services are achieved by improving facilities cleanliness, privacy settings and providing interpersonal services (Adhikary et al., 2018). Hospitals also need to pay attention about ongoing efforts to improve the collaboration and discipline between health professionals (de Oliveira et al., 2017). Nkwinda et al. (2019) also revealed that the hospital's high concern through the presence and nurses professional abilities could make patients satisfied with the services provided.

Siloam Hospitals Bali is part of the Siloam Group Hospital located in the Province of Bali. This hospital has become one of the private hospitals prepared to support medical tourism. Therefore, Siloam Hospitals Bali not only serves Indonesian patients, but also serves patients with foreign nationality. This can be seen from the results of preliminary studies obtained by the researcher on the number of tourists who have been hospitalized at Siloam Hospitals Bali from 2017 to 2019 , respectively amounting to $1,269,1,303$ and 1,402 patients.

The change in number of inpatients at Siloam Hospitals Bali every year is a reflection of the patient satisfaction level with the care service received. These are certainly influenced by efforts to improve accreditation which demands a health service facility also to improve the treatment process provided (Alkhenizan \& Shaw, 2011). However, the presence of patient-related factors, such as socio-demographic characteristics, could also affect the patients' satisfaction level during hospitalization. Therefore, patient satisfaction needs to be explored on an ongoing basis to identify variables that can influence patient responses during treatment and find out the changes needed to perform nursing care. This study aims to identify the differences of inpatients' satisfaction level based on socio-demographic characteristics at Siloam Hospitals Bali.

\section{MATERIALS AND METHODS}

This study is a non-experimental research with descriptive comparative and correlation methods and a cross sectional research design. The variables examined in the study were patient satisfaction as the dependent variable and socio-demographic characteristics (age, sex, education, marital status, and nationality status) as independent variables.

This study was conducted at inpatient installation of Siloam Hospitals Bali with the selected room number as research locations, namely four inpatient rooms consisting of Inpatient Department (IPD) -1, $2,-3$, and Maternity Ward. The population in the study were all inpatients at Siloam Hospitals Bali. The inclusion criteria used in this study are: patients aged $\geq 12$ years; inpatients at Siloam Hospitals Bali who declared allowed going home, willing to be the subject by signing informed consent, able to understand Indonesian or English. Meanwhile the exclusion criteria from this study are: patients in decreased consciousness condition and patients with cognitive impairment. This study also used dropout criteria, such as patients who did not fill the instruments completely and lost patients.

This study obtained a sample size of 107 patients selected using a non-probability sampling technique with purposive sampling. The research instrument used in this study was the Patient Satisfaction with Nursing Care Quality Questionnaire (PSNCQQ). The PSNCQQ was developed by Laschinger et al. (2005) to measure patient satisfaction with the nursing services quality. The PSNCQQ instrument validity and reliability test was carried out on 445 patients in Canada and the results showed that the PSNCQQ has excellent psychometric with 0.97 Cronbach's alpha reliability and correlation items ranging from 0.61 to 0.89 (Laschinger et al., 2005). The PSNCQQ instrument was also tested in several developing countries, such as Serbia $(\mathrm{n}=240)$ and Poland $(\mathrm{n}=$ 85); the results showed that the PSNCQQ instrument is valid and reliable (Ksykiewicz-Dorota et al., 2011; Milutinović et al., 2012).

The PSNCQQ instrument consists of 19 questions summarized in nine dimensions, namely individual assessment, nurses' attention, nurse abilities and skills, staff collaboration, comfort, nurse response, and information provided by nurses, return instructions and coordination after patients discharged. Data were collected through instruments given to patients after patients were declared as discharge allowed. The researcher also obtained 
ethical clearance from the research ethics commission, prior to data collection.

The analysis test used in this study is the Spearman correlation test to determine the differences in satisfaction levels based on age, the Mann-Whitney test to determine the levels of satisfaction differences based on sex, marital status and nationality, as well as Kruskal-Wallis test to determine the differences in patient satisfaction levels based on education level.

\section{RESULTS}

Social demographic characteristics description and patient satisfaction are seen in Table 1 . The patients' age characteristics in this study indicate that the mean age of patients is 41 years with the youngest age being 12 years and the oldest age being 74 years. Patient characteristics based on sex, education level, marital status and nationality showed that the majority of patients were male (51.4\%), tertiary educated (46.7\%), married (74.8\%), and Indonesian $(80.4 \%)$ The patient satisfaction description to nursing services shows that of the 107 patients undergoing hospitalization, it was found that the median patient satisfaction score was 75 with the lowest satisfaction score being 50 and the highest satisfaction score 95 .

The analysis of inpatient satisfaction levels differences based on age, gender, education level, marital status and nationality are seen in Table 2 . The differences analysis of inpatient satisfaction levels by age shows that there is a weak significant relationship with the negative correlation direction between patient satisfaction levels and age. The analysis shows that age can influence the level of patient satisfaction with weak strength $(\mathrm{p}$ value $=0.017 ; \mathrm{r}=-0.231 ; \alpha$ $<0.05$ ). The differences analysis of inpatient satisfaction levels by sex shows that the median value of patient satisfaction is found higher in men (76)

Table 1. The differences analysis of inpatient satisfaction levels by age, sex, education level, marital status and nationality

\begin{tabular}{|c|c|c|}
\hline Variable & n (\%) & Median (Min-Max) \\
\hline Age (Years) & - & $41(12-74)$ \\
\hline \multicolumn{3}{|l|}{ Gender } \\
\hline Male & $55(51,4)$ & - \\
\hline Female & $52(48,6)$ & - \\
\hline \multicolumn{3}{|l|}{ Level of Education } \\
\hline Primary Education & $8(7,5)$ & - \\
\hline Secondary Education & $49(45,8)$ & - \\
\hline Tertiary Education & $50(46,7)$ & - \\
\hline \multicolumn{3}{|l|}{ Marital Status } \\
\hline Married & $80(74,8)$ & - \\
\hline Unmarried & $27(25,2)$ & - \\
\hline \multicolumn{3}{|l|}{ Nationality } \\
\hline Indonesian & $86(80,4)$ & - \\
\hline Non-Indonesian & $21(19,6)$ & - \\
\hline Patients satisfaction & - & $75(50-95)$ \\
\hline
\end{tabular}

Tabel 2. The Differences Analysis of Inpatient Satisfaction Levels by Age, Sex, Education Level, Marital Status and Nationality

\begin{tabular}{|c|c|c|c|c|}
\hline \multirow[b]{2}{*}{ Variable } & \multicolumn{4}{|c|}{ Patient Satisfaction } \\
\hline & $\mathbf{n}$ & $\begin{array}{c}\text { Median } \\
(\text { Min-Max) }\end{array}$ & Mean Rank & p-value \\
\hline Age & 107 & - & $-0,231^{\#}$ & $0,017^{*}$ \\
\hline \multicolumn{5}{|l|}{ Gender } \\
\hline Male & 55 & $76(56-95)$ & 57,17 & \multirow[t]{2}{*}{$0,276^{* *}$} \\
\hline Female & 52 & $74,5(50-95)$ & 50,64 & \\
\hline \multicolumn{5}{|l|}{ Education Level } \\
\hline Primary Education & 8 & $79(57-95)$ & 65,38 & \multirow{3}{*}{$0,434^{* * *}$} \\
\hline Secondary Education & 49 & $76(55-95)$ & 55,31 & \\
\hline Tertiary Education & 50 & $70,5(50-95)$ & 50.90 & \\
\hline \multicolumn{5}{|l|}{ Marital Status } \\
\hline Married & 80 & $73(50-95)$ & 50,36 & \multirow[t]{2}{*}{$0,036^{* *}$} \\
\hline Unmarried & 27 & $79(55-95)$ & 64,78 & \\
\hline \multicolumn{5}{|l|}{ Nationality } \\
\hline Indonesian & 86 & $72,5(50-95)$ & 48,87 & \multirow[t]{2}{*}{$0,001^{* *}$} \\
\hline Non-Indonesian & 21 & $85(57-95)$ & 75,02 & \\
\hline : coefficient correl & & & & \\
\hline : Spearman Correl & & & & \\
\hline : Man-Whitney tes & & & & \\
\hline : Kruskal-Wallis te & & & & \\
\hline
\end{tabular}


than women (74.5). Statistical test results showed that there was no significant difference between satisfaction scores in male and female patients at Siloam Hospitals Bali ( $\mathrm{p}$ value $=0.276 ; \alpha<0.05$ ).

The differences analysis of inpatient satisfaction level based on the level of education obtained the result that the higher median value of patient satisfaction was found in primary educated patients (79), compared to secondary educated (76) and tertiary educated (70.5). Statistical test results showed that there was no significant differences between satisfaction scores in primary, secondary and tertiary educated patients at Siloam Hospitals Bali $(p$ value $=0.434 ; \alpha<0.05)$. The differences analysis of inpatients' satisfaction level based on marital status obtained results that a higher median value was found in patients who were single (79) compared to those who were married (73). Statistical test results show that there were significant differences between the patient satisfaction scores with married and unmarried status at Siloam Hospitals Bali ( $p=0.036 ; \alpha<0.05)$. The differences analysis of inpatients' satisfaction level based on nationality shows higher median score found in nonIndonesian patients (85) compared to Indonesian patients (72.5). Statistical test results show that there is a significant difference between satisfaction scores in Indonesian patients and non-Indonesian patients in Siloam Hospitals Bali ( $p$ value $=0.001 ; \alpha<0.05$ ).

\section{DISCUSSION}

\section{Inpatient satisfactions' overview}

This study results indicated that all inpatients satisfaction scores were in range 50 to 95 . Based on the median values obtained, these findings indicated that the patient satisfaction score is close to the maximum, which is 95 . According to Thapa and Joshi (2019), the patient satisfaction level value with the care quality measured using the PSNCQQ instrument divided into two categories, which were good patient satisfaction (median $\geq 70$ ) and poor patient satisfaction (median $<70$ ). Based on these categories, the median patient satisfaction score found in this study is categorized as good. This proves that inpatients at Siloam Hospitals Bali as a whole were satisfied with the nursing services received.

This study result is in line with the Thapa and Joshi (2019) study at one hospital in Chitwan City, Nepal, which found that the majority of patients had good satisfaction $(50.5 \%)$. Research by Konduru et al. (2015) which categorizes the patient satisfaction level as good, moderate and bad also supports this study result, namely the majority of patients hospitalized at a public hospital in India have good satisfaction $(66 \%)$ of nursing care services.

In the all items results of the statements given, the majority of inpatients gave a good evaluation value. This study shows that inpatients at Siloam Hospitals Bali received good quality nursing services. This is because the service quality will positively influence patient satisfaction, i.e. the better service quality, the higher patients satisfaction (Sulistyo et al., 2019).

Nursing services are professional services performed by nurses in accordance with service standards with the aim of delivering services that exceed patient expectations (Nursalam, 2014). Nursalam (2014) explains that the high and low level of patient expectations about the service quality can also be influenced by four interrelated factors, wordof-mouth communication, personal needs, past experiences and external communication (company's external communication). This shows that, in addition to factors in the nursing services quality, the gap between patient expectations and the care quality received can also affect patient satisfaction. The service quality could be defined to meet satisfying if the expected service is the same as perceived. Similarly, a service is said to not meet expectations or is not qualified if the expected service is greater than the perceived service (Nursalam, 2014).

This study also shows that hospital care management has been able to understand patient expectations, and that the majority of patients have good satisfaction. This is explained in the Grand Theory developed by Parasuraman (cited in Nursalam, 2014) related to gaps in service quality, as patient dissatisfaction can occur when the management of healthcare institutions has not been able to correctly identify and understand the health service users' expectations.

\section{Differences in Patient Satisfaction Levels by Age}

Based on this study's results, shows that there are differences in the inpatient satisfaction level based on age. Based on Rank Spearman test, there is a weak significant relationship with the negative correlation direction between the satisfaction level and patients' age. These results indicated that the younger the patient, the satisfaction will increase, while the older the patient, the satisfaction level will be lower.

This study results are supported by Batbaatar et al. (2017) who revealed that age as a demographic characteristic factor could influence the patient satisfaction level. Karaca and Durna (2019) also found that patients aged $>65$ years or patients with an older age tend to give less satisfied quality of care ratings compared to other age groups. Other research related to public satisfaction with the health system performance also found that the younger age group had higher satisfaction than the older age group (Footman et al., 2013).

Other studies related to patient satisfaction with the nursing care quality found different results. Chen et al. (2019) found that younger patients tended to show lower satisfaction compared to older patients. This is in line with research by Dzomeku et al. (2013) who found that patients with age $<40$ years tend to feel less satisfied with care services than patients aged $>40$ years.

Older patients tend to be more satisfied with care services because elderly people generally 
experienced chronic diseases. This condition causes them to be more receptive to their physical limitations than younger. This will encourage older patients to have lower demands and expectations. Therefore, older patients are generally more satisfied with care services than younger (Haj-Ali et al., 2014). In addition, the existence of cultural values factors, such as parents must be more respected and given special privileges, affects satisfaction because nurses will pay more attention to older than younger patients (Dzomeku et al., 2013).

Although the age factor can be said to be consistent, the relationship between age and satisfaction is still in a nonlinear pattern. This is proved by the findings, which stated that patient satisfaction increases until the age of 40 years, but can decrease sharply after 40 years (Amro et al., 2018). The variation in differences in the patient satisfaction level due to age is caused by several things, such as differences in cultural values, less positive patient responses, tolerance levels in each individual patient and age-related maturity levels (Karaca \& Durna, 2019).

The differences results found in this study were caused by differences of patient needs that affect patient care services expectations. Karaca and Durna (2019) state that the low level of satisfaction in the patients group with older age is caused by the nurses' lack of attention in providing care to the elderly. This can lead to differences in patient needs, i.e. older patients have unique needs during treatment compared to younger. According to Chumbler et al. (2016), the differences in needs is caused by the inherent heterogeneity in the elderly patient group, the complex health status experiences, health wrong perceptions, and an illness history due to age.

These findings indicated that inpatient care providers need to pay special attention when providing care to older patients. One way is to improve and maintain communication between nurses and patients. Chumbler et al. (2016) revealed that nurses' communication was the second most influential factor on care satisfaction in a group of patients with older age ( $>70$ years). In addition, Salehi et al. (2018) argued that older patients will feel more satisfied with healthcare if they receive more respect and attention. Therefore, inpatient care providers need to improve care services by ensuring good communication by nurses and maintaining the nursing staff's responsiveness to patient needs so that overall care can be patient-centered.

\section{Differences in Patient Satisfaction Levels based on Gender}

This study results obtained statistical data that showed that there were no differences in the patient satisfaction level by sex. This study is supported by the research of Karaca and Durna (2019) who found that there were no significant differences in satisfaction levels between male and female patients. Alsaqri (2016), in her research, also found the same, that there were no significant differences in satisfaction between men and women in providing nursing care evaluation.

Gender is a factor that still has strength and direction of the association that is not consistent with patient satisfaction (Batbaatar et al., 2017). This is proved by Chen et al. (2019) research which found that patients with female sex had higher levels of satisfaction compared to male patients. Other studies have found different results, namely male patients tend to feel more satisfied with treatment compared with female patients (Dzomeku et al., 2013).

Gender could affect patient satisfaction because they have different views of the hospital services provided. Women tend to pay more attention to the appearance in details, whereas men generally do not attach importance to it (Oroh et al., 2014). Those female patients will be more careful and critical of the quality aspects when evaluating the performance of service provider staff (Dzomeku et al., 2013). In addition, men also have different ways in managing relationships with women. Men tend to be more ignorant about what is stated by women, and they are considered more flexible (Gunarsa cited in Oroh et al., 2014).

This study found that gender did not affect inpatient satisfaction. Aspects that came from care service providers, such as hospital accreditation status, caused this. This is because good accreditation status will require hospitals to improve the services quality provided. Quality improvement could see from the hospitals efforts to improve cooperation and discipline among health workers in providing services (de Oliveira et al., 2017). In addition, accreditation is a determinant of patient satisfaction because of the complete hospital facilities and infrastructure support (Haj-Ali et al., 2014).

In addition to the factors originating from the care provider, the length of stay in the hospital can also affect patient satisfaction. According to Sulistyo et al. (2019), patient's length of stay can significantly affect patient satisfaction positively. This is because patients treated for a long time feel that they have received more attention (Salehi et al., 2018). Longterm treatment will also increase the health workers' attention and empathy to patients, then patients generally will more feel comfortable (Sulistyo et al., 2019).

\section{Differences in Patient Satisfaction Levels based on Education Level}

Based on this study, results showed that there were no differences in patient satisfaction levels based on primary, secondary and tertiary education levels. This is in line with Konduru et al. (2015) and Edmealem et al. (2019) who found that there were no significant differences in patient satisfaction with nursing care based on the level of patient education.

This study results differ from those of Amro et al. (2018) who found that patients with master's education had higher satisfaction compared to 
bachelors, diploma and no education certificates. This is supported by Chen et al. (2019) who found that the majority of low satisfaction was experienced by less education patients and who did not have an education degree. This can be caused by the influence of the patient's education level on communication skills. Highly educated patients are better able to listen and integrate the opinion differences along with medical services (Amro et al., 2018). Bu-Alayyan (cited in Baltaci et al., 2013) also revealed that patients with high levels of education more easily communicate with medical personnel.

Other studies have also found different results, namely illiterate patients and only primary education patients tend to be satisfied with treatment (Dzomeku et al., 2013). Low-educated patients are more satisfied with the service because they do not have more information about the treatment they will receive, so they do not place high expectations on the service provider. Salehi et al. (2018) also supported that the majority of patients with low education did not have sufficient access to know good health service standards. Dzomeku et al. (2013) also argued that highly educated patients tend to be less satisfied because they are more able to access information about nurses' tasks. In addition, highly educated patients have obtained more information about the alternative treatments they will receive, so they will expect a higher care standard (Karaca \& Durna, 2019).

In addition to accessing information easily, service quality can also affect patient satisfaction, i.e. the better service quality, the higher the patients' satisfaction. This is because good service quality will increase the speed of the service process provided, such as the easy registration administration process, nurses working systematically and effectively, and arrival on time, then patients will feel more satisfied and provide a positive assessment (Fuad et al., 2019).

\section{Differences in Patient Satisfaction Levels based on Marital Status}

Based on this research, the results show that there is a significant difference between the satisfaction of married and unmarried patients. This study analysis results indicated that unmarried patients have higher satisfaction than married patients. Marital status is categorized as either unmarried patient who is unmarried, divorced and dead divorced, or as a married patient, who is married and having married status.

This study finding are supported by Karaca and Durna (2019) who stated that marital status influences patient satisfaction. The study found that patients with divorced status had higher satisfaction with nursing services compared to patients who were married. This study results are also in line with the Akbas (2019) study at obstetrics and gynecology clinics in several hospitals types. The study found that single-status patients were more satisfied with nursing care services than married patients.
One study found different results, i.e. married patients were more satisfied with health services than single patients, divorced or patients living with partners (Ayranci \& Atalay, 2019). Edmealem et al. (2019) also found that married patients were more satisfied with nursing care than single patients were. Although marital status is a contradictory factor in influencing patient satisfaction, other studies have found that there is no significant difference in satisfaction between married and single or unmarried patients (Konduru et al., 2015; Olomi et al., 2017).

This study found that unmarried patients tended to be more satisfied with nursing services. This tendency is attributed to the satisfaction description results based on the age characteristics found in this study, namely patients with younger ages tend to be more satisfied with care services. This is because the majority of unmarried individuals are younger, i.e. 017 years (99.94\%) (Kementerian Pemberdayaan Perempuan and Perlindungan Anak RI, 2019). However, this relationship is used as a basis if the status category of unmarried patients is divorced or divorced. This is because the majority of divorced and dead divorced people is experienced by the age group of 45 years and over, which is $2.28 \%$ and $35.80 \%$, respectively (Badan Pusat Statistik, 2018), while the percentage of divorced life and death divorce experienced by the age group of 10 to 17 years is only 0.04\% (KPPPA RI, 2019).

If the patient satisfaction tendency categorized as unmarried occurs in patients with divorce status, this can be related to their older age. According to Chen et al. (2019), older patients will be more satisfied with the services received. This is because older patients are more receptive to their physical limitations, causing them to tend to have lower demands and expectations (Haj-Ali et al., 2014).

In addition to the age influence, aspects that come from healthcare providers, such as the environment, can also cause the satisfaction tendency found in patients who are not married. Quintana (cited in Batbaatar et al., 2017), supports this in stating that patients with single or divorced status tend to be more satisfied with health services, especially in the comfort and hygiene aspects. This is because a satisfying physical environment, such as clean clothing availability, clean bedding and clean food will be considered as a good care evidence (Heidari et al., 2017).

These findings indicated that to be able to know differences in satisfaction levels based on marital status more clearly, it is necessary to identify the satisfaction scores proportion based on the category of single, married, divorced and dead divorced. It aims to analyze deeply the effect of marital status on patient satisfaction. 


\section{Differences in Patient Satisfaction Levels based on Nationality}

Based on the study result, obtained statistical data show that there are significant differences between the satisfaction of Indonesian patients and nonIndonesian patients. This study analysis results indicated that the patients with foreign nationality have higher satisfaction than Indonesian nationality.

This study results are different from research conducted by Chaker and Al-Azzab (2011) related to the relationship between patient nationality and satisfaction scores at one of the specialized athlete hospitals in Qatar and which found that participants with Qatar nationality had higher satisfaction with hospital services compared to participants of European, Asia, North Africa, America and other countries. AlNemer et al. (2015) also conducted a similar study at a primary healthcare clinic in Riyadh, Saudi Arabia. This study results found no significant differences in patients' satisfaction between those who were Saudi Arabian and patients who were not.

The satisfaction tendency in non-Indonesian patients found in this study can be caused by differences in the patient's work status. Based on the survey, the number of foreigners who came to Bali in 2018 with a health tourism aim reached $6,070,473$ (Bali Goverment Tourism Office, 2019). The data show that the majority of patients undergoing treatment at Siloam Hospitals Bali are foreigners. This refers to their activities while living in Bali, which is the majority of trips compared to work. Sulistyo et al. (2019) revealed that patients who did not work had higher satisfaction than patients who worked. This is because individuals who work generally have a habit of always focusing on the services, they should get to suit their needs. Therefore, individuals who work tend to be very dependent on health services, while individuals who do not work will tend to be more independent (Lupiyoadi cited in Sulistyo et al., 2019).

In addition to the influence of differences in patient work status, the strategic location of the hospital and the tourism area can also affect the satisfaction of non-Indonesian patients compared to Indonesian patients. Damghi et al. (2013) found that patients who lived within 10 kilometers of the hospital tended to be more satisfied than patients who lived more than 10 kilometers. Based on the observations, Siloam Hospitals Bali is located in the Kuta district, which causes this hospital to be the main health service access for tourists. Patients who are foreigners will be more satisfied because the location of a hospital that is easily accessible means patients get emergency care more quickly. This is also supported by Amro et al. (2018) who stated that patients who live in cities are more satisfied than patients who live in villages, because most private and government hospitals are located in cities.

\section{CONCLUSION}

Based on the research, it can be concluded that age can influence inpatient satisfaction with weak strength and negative correlation direction. Other socio-demographic characteristics factors that were found to influence inpatient satisfaction were marital status and nationality, while gender and education level were found to have no significant effect on patient satisfaction. Overall, inpatients provide good satisfaction evaluations of nursing care.

\section{REFERENCES}

Adhikary, G., Shajedur Rahman Shawon, M., Wazed Ali, M., Shamsuzzaman, M., Ahmed, S., Shackelford, K. A., Woldeab, A., Alam, N., Lim, S. S., Levine, A., Gakidou, E., \& Jasim Uddin, M. (2018). Factors influencing patients' satisfaction at different levels of health facilities in Bangladesh: Results from patient exit interviews. PLOS ONE, 13(5), 1-13. https://doi.org/10.1371/journal.pone.0196643

Akbas, M. (2019). Patient satisfaction on nursing care: The case of gynecology and obstetrics clinics. Acta Bioethica, 25(1), 127-136. https://doi.org/10.4067/S1726569X2019000100127

Alkhenizan, A., \& Shaw, C. (2011). Impact of accreditation on the quality of healthcare services: A systematic review of the literature. Annals of Saudi Medicine, 31(4), 407-416. https://doi.org/10.4103/0256-4947.83204

AlNemer, K. A., Al-Homood, I. A., AlNemer, A. A., Alshaikh, O. M., Alsaidan, M. A., \& Alzahrani, A. T. (2015). A multicenter study of factors affecting patient's satisfaction visiting primary health care clinics in Riyadh, Saudi Arabia. Family Medicine and Medical Science Research, 4(2), 1-4. https://doi.org/10.4172/2327-4972.1000169

Alsaqri, S. (2016). Patient satisfaction with quality of nursing care at Governmental Hospitals, Ha'il City, Saudi Arabia. Journal of Biology, Agriculture and Healthcare, 6(10), 128-142. https://www.iiste.org/Journals/index.php/JBAH /article/view/30595

Amro, N., Kamel, A. M. A., Qtait, M., Yagi, H., Amro, B., Amro, R., \& Amro, R. (2018). Factors affect patients satisfaction in Emergency Departments in Palestine. Journal of Health, Medicine and Nursing, 54(1), 3-8. https://www.researchgate.net/publication/3280 31303

Ayranci, E., \& Atalay, N. (2019). Demographic determinants of patient satisfaction: A study in a Turkish context. International Journal of Academic Research in Business and Social Sciences, 9(6), 829839. https://doi.org/10.6007/ijarbss/v9i6/6041

Badan Pusat Statistik. (2018). Statistik Penduduk Lanjut Usia Tahun 2018. BPS Jakarta.

Bali Goverment Tourism Office. (2019). Direct Foreign Tourist Arrivals to Bali in 1971-2018. 
https://disparda.baliprov.go.id/

Baltaci, D., Eroz, R., Ankarali, H., Erdem, O., Celer, A., \& Korkut, Y. (2013). Association between patients' sociodemographic characteristics and their satisfaction with primary health care services in Turkey. Kuwait Medical Journal, 45(4), 291-299. https://www.researchgate.net/publication/2872 73429

Batbaatar, E., Dorjdagva, J., Luvsannyam, A., Savino, M. M., \& Amenta, P. (2017). Determinants of patient satisfaction: A systematic review. Perspectives in Public Health, 137(2), 89-101. https://doi.org/10.1177/1757913916634136

Chaker, M., \& Al-Azzab, N. (2011). Patient satisfaction in Qatar Orthopedic and Sports Medicine Hospital (ASPITAR). International Journal of Business and Social Science, 2(7), 69-78. https://www.semanticscholar.org/

Chen, Q., Beal, E. W., Okunrintemi, V., Cerier, E., Paredes, A., Sun, S., Olsen, G., \& Pawlik, T. M. (2019). The association between patient satisfaction and patient-reported health outcomes. Journal of Patient Experience, 6(3), 201209.

https://doi.org/10.1177/2374373518795414

Chumbler, N. R., Otani, K., Desai, S. P., Herrmann, P. A., \& Kurz, R. S. (2016). Hospitalized Older Adults ' Patient Satisfaction: Inpatient Care Experiences. 2016. https://doi.org/10.1177/2158244016645639

Damghi, N., Belayachi, J., Armel, B., Zekraoui, A., Madani, N., Abidi, K., Benchekroun, A. B., Zeggwagh, A. A., \& Abouqal, R. (2013). Patient satisfaction in a Moroccan Emergency Department. International Archives of Medicine, 6(20), 1-8. https://doi.org/10.1186/1755-76826-20

de Oliveira, J. L. C., Gabriel, C. S., Fertonani, H. P., \& Matsuda, L. M. (2017). Mudanças gerenciais resultantes da Acreditação hospitalar. Revista Latino-Americana de Enfermagem, 25, 1-8. https://doi.org/10.1590/1518-8345.1394.2851

Dzomeku, V. M., Atinga, Ba-Etilayoo, Perekuu, T., \& Mantey, R. E. (2013). In-patient satisfaction with nursing care: A case study at Kwame Nkrumah University of Science and Technology Hospital. International Journal of Research In Medical and Health Sciences, 2(1), 1-6. http://www.ijsk.org/ijrmhs.html

Edmealem, A., Asfaw, Y., \& Ademe, S. (2019). Patients' satisfaction and associated factors towards nursing care in Dessie Referral Hospital, Northeast Ethiopia. Clinical Journal of Nursing Care and Practice, 3, 53-58. https://www.heighpubs.org/hjncp

Footman, K., Roberts, B., Mills, A., Richardson, E., \& McKee, M. (2013). Public satisfaction as a measure of health system performance: A study of nine countries in the former Soviet Union. Health Policy, 112(1-2), 62-69. https://doi.org/10.1016/j.healthpol.2013.03.004

Fuad, L., Tamtomo, D., \& Sulaeman, E. S. (2019).
Multilevel analysis on the effect of marketing mix strategy toward patient satisfaction in Magelang, Central Java. Journal of Health Policy and Management, 4(1), 39-46. https://doi.org/10.26911/thejhpm.2019.04.01.0 5

Haj-Ali, W., Karroum, L. B., Natafgi, N., \& Kassak, K. (2014). Exploring the relationship between accreditation and patient satisfaction-the case of selected Lebanese hospitals. International Journal of Health Policy and Management, 3(6), 341-346. https://doi.org/10.15171/ijhpm.2014.116

Heidari, M., Pour, H., Norouzzadeh, R., Temel, E., \& Şahin, B. (2017). Assessment patients' satisfaction related on quality of care: A Cross-sectional descriptive study. Asian Journal of Medicine and Health, 5(4), 1-8. https://doi.org/10.9734/ajmah/2017/34513

Karaca, A., \& Durna, Z. (2019). Patient satisfaction with the quality of nursing care. Nursing Open, 6(2), 1-11. https://doi.org/10.1002/nop2.237

Kementerian Pemberdayaan Perempuan dan Perlindungan Anak RI. (2019). Profil Anak Indonesia Tahun 2018.

Konduru, A., Sujatha, T., \& Judie, A. (2015). A study to assess the level of patient satisfaction on quality of nursing care among patients in SRM general hospital, kattankulathur. International Journal of Pharmaceutical and Clinical Research, 7(6), 458461.

https://www.researchgate.net/publication/3030 89344

Ksykiewicz-Dorota, A., Sierpińska, L., Gorczyca, R., \& Rogala-Pawelczyk, G. (2011). Polish version of patient satisfaction with Nursing Care Quality Questionnaire (PSNCQQ). Progress in Health Sciences, 1(1), 51-56.

Laschinger, H. S., Hall, L. M., Pedersen, C., \& Almost, J. (2005). A psychometric analysis of the patient satisfaction with nursing care quality questionnaire. Journal of Nursing Care Quality, 20(3), 220-230. https://doi.org/10.1097/00001786-20050700000006

Milutinović, D., Simin, D., Brkić, N., \& Brkić, S. (2012). The patient satisfaction with nursing care quality: The psychometric study of the Serbian version of PSNCQ questionnaire. Scandinavian Journal of Caring Sciences, 26(3), 598-606. https://doi.org/10.1111/j.14716712.2012.00969.x

Mohan, D. R., \& Kumar, K. S. (2011). A study on the satisfaction of paitnets with reference to hospital services. ZENITH International Journal of Business Economics \& Management Research, 1(3), 15-25. http://zenithresearch.org.in/

Mukhtar, F., Anjum, A., Bajwa, M., Shahzad, S., Hamid, S., Masood, Z., \& Mustafa, R. (2013). Patient Satisfaction. Professional Med J, 20(6), 973-980. https://doi.org/10.3109/9780824706081.114

Mumu, L. J., Kandou, G. D., \& Doda, D. V. (2015). Analisis faktor-faktor yang berhubungan dengan 
kepuasan pasien di Poliklinik Penyakit Dalam RSUP Prof . Dr . R . D . Kandou Manado. Jurnal Unsrat, $5(4)$. https://ejournal.unsrat.ac.id/index.php/jikmu/ar ticle/view/7460

Mustika, D., \& Sari, K. (2019). Kepuasan pasien terhadap layanan rawat inap RSUD Jagakarsa tahun 2017/2018. Jurnal ARSI, 5(3), 147-152. http://journal.fkm.ui.ac.id/arsi/article/view/295 0

Nkwinda, B., Jacobs, W., \& Downing, C. (2019). Patient satisfaction with caring at a district hospital in Malawi. Global Journal of Health Science, 11(1), 15-27. https://doi.org/10.5539/gjhs.v11n1p15

Nursalam. (2014). Manajemen Keperawatan: Aplikasi Keperawatan Profesional (4th ed.). Selemba Medika.

Novitasari, A., Hidayat, M., \& Kaporina, A. (2014). Kepuasan pasien rawat inap terhadap pelayanan keperawatan di RSUP Dr. Kariadi Semarang. Jurnal Kedokteran Muhammadiyah, 3(1). https://jurnal.unimus.ac.id/index.php/kedoktera n/article/view/2553

Oini, O., Komalasari, R., \& Hasibuan, S. Y. (2017). Tingkat kepuasan pasien terhadap pelayanan keperawatan di unit rawat inap. Nursing Current, 5(2),

50-60. https://ojs.uph.edu/index.php/NCJK/article/vie $\mathrm{w} / 1707$

Olomi, G., Mboya, I., \& Manongi, R. (2017). Patients' level of satisfaction with the health care services received at outpatient departments in Kilimanjaro Region, Tanzania. Journal of Patient Care, 3(1). https://doi.org/10.4172/2573-4598.1000124

Oroh, M. E., Rompas, S., \& Pondaag, L. (2014). Faktorfaktor yang berhubungan dengan tingkat kepuasan pasien rawat inap terhadap pelayanan keperawatan di Ruang Interna Rsud Noongan. Jurnal Keperawatan, 2(2). https://ejournal.unsrat.ac.id/index.php/jkp/artic le/view/5220

Peraturan Menteri Kesehatan Republik Indonesia Nomor 129 Tahun 2008 tentang Standar Pelayanan Minimal Rumah Sakit.

Price, R. A., Elliott, M. N., Zaslavsky, A. M., Hays, R. D., Lehrman, W. G., Rybowski, L., Edgman-Levitan, S., \& Cleary, P. D. (2014). Examining the role of patient experience surveys in measuring health care quality. Medical Care Research and Review, 71(5), 522-554 https://doi.org/10.1177/1077558714541480

Salehi, A., Jannati, A., Nosratnjad, S., \& Heydari, L. (2018). Factors influencing the inpatients satisfaction in public hospitals: a systematic review. Bali Medical Journal, 7(1), 17. https://doi.org/10.15562/bmj.v7i1.533

Sulistyo, S. A., Tamtomo, D., \& Sulaeman, E. S. (2019). Accreditation Status and Other Factors Affecting Patient Satisfaction in Hospital. Journal of Health Policy and Management, 4(3), 139-149. https://doi.org/10.26911/thejhpm.2019.04.03.0 1

Thapa, S., \& Joshi, A. (2019). Patients' satisfaction with quality nursing care at teaching hospital, Chitwan. Journal of Nursing and Health Science (IOSR-JNHS), 8(3), 71-75. https://doi.org/10.9790/19590803077175

World Health Organization. (2015). Health in 2015 from MDGs to SDGs. https://www.who.int/gho/publications/mdgssdgs/en/

Worku, M., \& Loha, E. (2017). Assessment of client satisfaction on emergency department services in Hawassa University Referral Hospital, Hawassa, Southern Ethiopia. BMC Emergency Medicine, 17(1), 1-5. https://doi.org/10.1186/s12873-0170132-7 